\title{
THE HISTORY OF THE FRANKFURT SCHOOL FROM CRITICISM TO EMANCIPATION MOVEMENT
}

\author{
Damanhuri Fatah ${ }^{1}$
}

\begin{abstract}
This paper describes the modern society's major basic idea which has been uphold by Frankfurt School, that is, the crisis of enlightenment, of art and culture, and of history. The school is trying to reunite concretely branches of knowledge in social sciences which have been broken down into pieces without sacrificing their good points. The school also intellectually and socially redefines Marxism in its period. The Frankfurt School of the first period was claimed to have been deadlock in taking part in solving the problem of modern world. The works of Karl Marx, Horkheimer, Adorno, as well as Herbert Marcuse are the severe criticisms on scientism and positivism. According to them, both have interfered modern society as uncovered in the instrumental and technological rationality. The critical tradition previously developed by Marx tried to uproot the hidden system in a certain ideology that had made the society's creative thinking less interisting. It means that the system which developed at that time was in fact the place where ideological interests of certain parties hid. Marx intended to uproot these interests which was the continued by the Frankfurt School community which was known for their ideological criticism.
\end{abstract}

Key Words: epistemology, Frankfurt School, Habermas, Emancipation

\footnotetext{
${ }^{1}$ Damanhuri Fatah, lecturer of IAIN Radean Intan Lampung. For academic interest, the author can be contacted at office address: Jl. Letkol H. Endro Suratmin Sukarame, Bandar Lampung.
} 


\section{Introduction}

There are three common names of Frankfrut School, without any particular difference: Institut for Sozialforshsung, Critical Theory, and Frankfrut School (Kolakowsky, 1978 : 341 - 343). The founder of the institute was a political expert named Felix J. Weil. He was the son of a tycoon, Herman Weil, who had spent all of his assets for funding social reseraches, particularly to revive the Mrax doctrin to be restructured in accordance with the era (Wiggershaus, 1994: 9, 12-13, 16-17).

At first it was the Institute for Sozialforschung (Institute for Social Research) which was founded in the early 1923 in Frankfurt, as one of the majors in Frankfurt University. The Institute's first director was Carl Grunberg. They had encountered a cultural crisis since 1890 with the rapid growth of capitalism in Germany. The German Institute brought this issue to the exile and later returned to Germany after the war with the new designation of "Frankfurt School". In such conditions, the Institute was still established, therefore, it is needed to be noted down and study all the six characteritic of the school:

1. First, using Marxism not as the basic norm (ideology), but only as a starting point and support for analysis and cultural criticism. Hence the critical analysis models of non-Marxis (Hegel, Kant, Nietzsche, Heidegger, Spengler, Freud, and Judaism) has become the choice.

2. Second, the programs structured are the programs expressing critical characteristics, and is non party (not part of a political movement).
3. Third, influenced by a new interpretation of Marxism by Georg Lukács and Karl Korsch in accordance with the problems of that time. The reflection concept of Lukacs becomes central.

4. Fourth, emphasizing on autonomous theories and object to directly involved (in practical political movement). The criticism over the society is limited only on academic movement, trying to transform the social reality through science.

5. Fifth, this School accepts some of Marx's theory such as the exploitation and alienation of labor; however, some views are objected, for example, class consciousness and revolution. The refication concept applied to all levels in the Marx's class division (bourgeois and proletarian classes).

6. Sixth, this school is the Revisionist movement of orthodox Marxism, and a revolutionary intellectuals (Kolakowsky, 1978: 341-343)

The early figures are Preidrich Pollock (1894-1970, an economist), Carl Grunber (1861-1940, the first director of the Institute), Max Horkheimer (1895-1973, philosopher, sociologist, psychologist, the scond director of the Institute), Karl Wittfogel ( born in 1869, historian, who view the Marxism influence in Asia), Wiesengrund Theodor Adorno (19031970, philosopher, sociologist, the third director of the Institute), Leo Lowenthal (born in 1900, a sociologist), Walter Benjamin (1892-1940, literary critic), Frank Neumann, (law expert), Hendryk Grossman (1881-1950, economists and political), Arkadij Gurland (economy and 
socialogy expert). They are the leaders of the Institute for Social Research

The school would like to try a more concrete way to reunite branches of knowledge in the social sciences that had been fragmented without sacrificing its positivity. The school also tried to redefine Marxism at that time intellectually and socially.

In the early 1930 the Institute released their interest on labor movements. During that time Marx Horkheimer was replacing Carl Grunberg position and become the leader of Zeitschrift fur Sozialforschung, a journal for Social Research) to replace the journals by Carl Grunberg, Archiv fur die Geschicte des Sozialismus und der Arbeiterbewegng (Discourse on History of Socialism and the Labour Movement). The main analysis subject was shifted from class analysis to culture and authority analysis. He "academized" politics (Gillian Rose, 1978: 2). Then the critical element in the historical process requires dealing with German authorities.

Under the leadership of Horkheimer both in Germany and during exile (United States), the instituion which had emphasized the conservatism and science during Carl Grunberg time, shifted their objective to emphasizing social research, technically and theoretically. Most articles of this school appeared in the themes that complained about the knowledge fragmentation during that time, the idea of totality as the missing perspective, resistance to positivism, and symptoms to return to the tradition of Gillian Rose, (1978: 2). This emphasis illustrates the fears of German academics against capitalism. The particularity of Frankfurt School is that it was always against idealism and the revival of Marxism after World War I. This school of social interests is to uncover the ideology of criticism and rejected claims of absolute validity.

The term "Frankfurt School" came into use around 1950 to refer back to the above Institute (Kolakowsky, 1978: 341). The term is synonymous with the redevelopment of the Institute after the war. The figures of Frankfrut School diminishing because many of them never returned from exile and no one returned to East Germany. They are Horkheimer, Adorno, Pollock, Marcuse, Lowenthal (two of them, Marcuse and Lowenthal lived in the U.S.)

The term "Critical Theory" refers to the paper of Horheimer, Kritische Theorie, which was written in 1937 and published in the Journal and republished in 1968. This paper talks about the projects of the Institute. The figures often called as the first generation of Critical Theory are Max Horkaeimer, Theodor Adorno, and Herbert Marcuse. While Jurgen Habermas is a Second Generation Critical Theory who has a similar point of view with Lukacs and Korsch in his interest in the legacy of German idealism, but in some cases they were also regarded as the successor to the spirit of the Left Wing Hegelianism in 1840 (Jay, 1973: 43-44),

The emerge of Frankrurt School is closely related to the views of Karl Marx and his successors (Marxist), especially western Marxism which is known as the Critical Marxism (Neo-Marxism). This school emerged as a reaction to the restriction of Karl Marx doctrins which was the ideology of the Communist Party of the Soviet Union (Arato and Gebhardt, 1978: 4-18). Many German academics reject the pro-Soviet Communist Party developed in 
Germany for betraying the doctrin of Marx and the Social Democratic Party who lost his Marxist nature. As a result they tried to define the Marx doctrine in accordance with the era. During that time they review the doctrin of Hegel which resurfaced idealism in Germany. The figures of the first wave of Neo-Maxis are including George Lukacs (1885-1971), Ernst Bloch (1885-1974), and Karl Korsch (1889-1963).

George Lukacs was actually the Hungarian Communist Party activist. His work, Geschichte und Klassenbewusstein (1923) (History and Class Consciousness) emphasizes on the awareness of proletarian class and excluding the automatic element (by itself) towards the history of capitalism that ended in accordance with Marxism Ortodiks. According to Lukacs, the suprastructure existed, the knowledge and ideology, need to be activated in order to enble changes (Wiggershaus, 1994: 15).

Ernist Bloch bought a big theme in his philosophical effort in the form of. The theme was connected with the matter of 'hope'. According to Bloch human life is intrinsically utopias. Utopia is a dream or human shadow about a better world that may not be realized in reality.

Opposed to most other Neo-Marxist philosophers, Ernst Bloch strongly emphasizes the nature dialectic: dealectic is just some part of them, even in principle of utopian world. Bloch was strongly influenced by the mystical tradition and eschatological thinking that philosophy was entering the otu of control mystical nature. It may be noted that Bloch was atheis, had a positive attitude toward religion because he considered it as an expression of utopian thinking.

Another Revisionist figure was Karl Korsch (1889-1963) of the German
Communist Party. His work Marxismus und Philosophie (1923) (Marxism and Philosophy), explaining that the doctrine of Marxism is a theory of his time with the material conditions that exist in society. Another figure, such as Antonio Gramschi called the view of the two figures mentioned above as the "philosophy of praxis" as it attempts to connect theory and praxis based on the doctrin of Marxism and German Idealism (Hegel) (Arato, 1982: 5). David Ryazanoov the director of Marx-Engels Institute in Moscow published the Paris Manuscript in 1932 which distribution was prohibited by the Marxists who want to redefine the Marx doctrines in accordance with the era (Winggershaus, 1994: 31-32, 615).

However, the political situation under communist during that time tested their views validity. Lukacs finally denied his views under the threat of the authority which at that time was on the hand of the Communist Party, while Korsch who did not want to deny his theory had to relinquish his membership in the Communist Party. The First Wave of Critical Marxism had faded. However, their theory had never gone and become the seeds for the emergence of the critical Second Wave Marxism which famous as the Frankfurt School.

\section{Historical Clausal of Frankfrut School}

The term of School (referred to 'stream') has various interpretation. The word school (mazhab) originated in fiqh term to refer to a branch of science that studies Islamic religious laws. Another interpretation of the school is mentioned in The Center Encyclopaedia of Islam, the term is defined as a system of thought (Suseno, 1992: 173). In Popular Dictionary 
of Islam, Jan. Richard Newton interpretes it as a group of thinkers or writers who engaged in law (Effendi (ed), 1999: 4). According to this point of view, no wonder if there was an institution of intellectual set called Frankfurt School (Die Frankfurter Schule) established in Germany in 1923, which became the embryo for the intellectual community that later known as the Frankfurt School.

Basically, the term of Frankfurt School is to indicate a movement of thought done at multidisciplinary by a group of intellectuals who focused their activities in the city of Frankfurt am Main, Germany, incorporated within the Institute for Social Research (Institut for Sarjal Forschung) pioneered by Feliy Weil, the son of a rich wheat merchant, Hermann Weil, and the bachelor of political science (Shindunata, 1983:20).Mostofthisinstitutionpopulation sympathized Marx (ism), and most of them were members of the Communist Party of Germany, therefore this research institution was called Café Marx (Adian, 2001: 56), means a community that seeks to 'refresh' and renew the thought of Karl Marx (1818 - 1883) which had been reduced and manipulated by some loyal followers and friends.

The misinterpretation of Marx's thought, happened when the thought was institutionalized as an ideology of the communist movement, the Marxism by Fricdricht Engels (1830 - 1895) and Vladimir Ilyic Ulyanof known as Lenin since the October Revolution of 1917 (Bolshevik Revolution)consideredMarxism-Leninism as an 'official' communism ideology in Russia. As a result, the revolutionary aspect of Marx's thought which tried to 'liberate' people from the supressed capitalism had actually developed as 'means' of new oppression (the ruler), as repressive as the previous. Instead of giving the 'meaning' of human liberation and alienation, the Marx institutionalization of Marxism and Marxism - Leninism had actually become dogmathat shacklesthefreedom of humans. According to Michael Hurrungton, Marx himself had always wanted the freedom of thought, therefore Marx condemned dogmatism in his works (Abdullah, 1974: 144). Marx saw that his theories was misinterpretated, that confessed, "As far as I know, I am not a Marxist” (Hatta, 1975: 17)

This misunderstanding has led Marx thoughts to be regarded as a 'ghost' terrifying everyone, especially for the people who had experienced the 'wound' of history and political trauma caused by communism. In fact, as a thinker, some of Marx's ideas was at first appeared as the counter dialogue of the thoughts of that era (Ramly, 2000: 6-7). Inspired by the spirit to 'straighten', 'refresh', and renew the misinterpreted of Marx thoughts, then the Frankfurt School was established.

The initial concept to renew Marx ideas had become an inspiration to the whole intellectual struggle in the community. Almost all the concepts were built based on some substantial aspects of Marx's theory. The basic spirit gave directions and characteristics of the community as the neo-Marxist of the contemporary which was influential and respected.

Some influenced thinkers (philosophers) in contemporary era, particularly in the social sciences, must have been born from the 'womb' of this school. Some of them are Pricdrick Pollock (economist), Walter Benjamin (literature critic), Max Hokheimer (sociologist), Theodor W. Adorno (musician, scholar, 
psychologist and philosopher), Herbert Marcuse (Martin Heidegger's student who tried to combine phenomenology and Marxism and known as the 'prophets' and 'inspiration' of New Left movement in the United States), Erich Fromm (expert of Freud psychoanalys), and so on. They were known as the first generation of the Frankfurt School. The last is Jurgen Habermas, the pioneer of critical sociology who was one the of the main successor of the second generation of the Frankfurt school.

However, it should be realized that the critical philosophy motivated by Hegel and Marx was not based on this school. If we trace the development of the West social sciences, the Marxism concept in its orthodox form had been critized since more than half a century ago,. Horkheimer (1895-19730) was not the first person who was not satisfied with the Orthodox Marxism, before him there were some revisionists such as Gramsci who rejected the principle of class conflict of Marx, in his Prison Notebooks - George Lucacs in his book entitled History and Class Corlsciousrless (1931), or Karl Korsch's Marxism and Philosophy (1923); aal of them are the neo-Marxist who are also very critical (Hardiman, 1993: xv-xvii) and (Sindhunata, 1983: 21-22). Eventhough for the other neo-Marxist, his third thought is considered inadequate for a social theory that could answer the challenges of the era. The Russian revolution spirit and his engagement to the party - the party in many ways regarded as the cause of the 'barren' of the critical aspects of the basic spirit developed .

Having 'handled' by Horkhcirnerlah, Marxism has a serious philosophical academic approach with the expectation to give the theoretical light on the social life pratice. By not worship it as the party's program, Horkheimer, through his Criticism Theory, tried to restore Marxism as critical philosophy, combined with the criticism of Kant, Hegel and Freud Psychoanalysis method. Theodor W. Adorno (1903 - 1969) and Herbert Marcuse (1898 - 1979) involvement has 'sharpened' and 'clarified' the stream of Frankfurt School critical conception of philosophy, by asking sharp criticism of the advanced industrial societies in the late 1960s (Hardiman, 1993: xvi).

\section{The Early Struggle of Frankfrut School}

This school was needed for a long timeto be theinfluencing stream in the contempory human "struggling" thoughts. In the early days, the 'echo' of Frankfurt school critical philosophy was not popular, especially among academics or philosophical fans. The critical theory become the matter of discussion among the philosophy and sociology people in 1961, after Deulsche Gesellschaft for Sosiologie had a meeting on 'the logic of social sciences', in which mentioned a sharp debate bertween Karl R. Popper and Theodore W. Adorno, and it was continued by Hans Albert on Popper's side and Jurgen Habermas on Adorno's side. In the debate, Adorno and Habermas labeled 'Critical Rationalism' of Popper and Albert as positivism, while Popper and Albert considered 'Critical Theory' of Adorno and his colleagues as totalitarian and full of myths (Suseno, in his preface in the book Sindhunata, 1983 : xiv). Since then the discourse of 'positivism debate in German sociology' had become the major themes of philosophy in Germany, and as the result of the Frankfurt School of 
Critical Theory become the main discourse in contemporary philosophical history in Germany.

Various social and political upheaval, occurred in the world in general and in Germany in particular, have influenced the development of frankfurt school. The repressive situation in 1933 during the racist goverment of Hitler's Nazi who commit 'genocide' to the Jews over the chaos caused by the World War II had sent the figures of this school to 'migrate' to the United States in 1934, because most of them were Jews. Their presence in the United States had him to make 'dialetics' with the characteristics of theories developed there. Intellectual discourse developed in the United States was quite influential to the model of thoughts of Frankfurt school, when this school returned to Germany in 1949. Jurgen Habermas was the figure of the school for the second generation. It was born from a sweet combination between German and the United States intellectual tradition (Ardyan, 2001: 53).

One interesting thing from this school, after this school returned to Germany was that it still had its critical tradition and found its 'moment' to be the inspiration for various social movements, paticularly the ones organized by students. Frankfurt school had been known as the inspiration of various student movements during 1960 s which known as "The New Left Morement", the sympathetic to any 'left' movement and against the steadyness. Unfortunately the movement patterns used by the student at that time was very revolusionary and dominated by violence. This pattern was (very) opposed by Hokheimer and Adorno, which caused students left them behind, because the Frankfurt school of thought no longer had 'fangs'. That is why the 'honeymoon' between the Frankfurt school and student activists only lasted until 1967.

Hokheimer and Adorno reject any revolutionary activism. Any attempt to use violence will only result in a more frightening slavery. For example, the effort to eliminate a repressive regime of Russian Tsar produced a more brutal regime, the regime dominated by the Communist Party which culminated in Stalinism. For them revolution will only restored a more evil repression.

However, in the situation like this the school of Frankfurt faced with a rational human effort dilemma (Sindhunata, 1983: 20). The Critical Theory has become an anti-praxis, which is 'out' of the initial enthusiasm which was to direct the theory to praxis toward emancipatory. Therefore to 'get out' from being stuck in this 'epistemology', the open only way was resognation, the withdrawal of the consciousness that refuses to be occupied by the system; the thought, philosophy, politics, or ideology.

Regardless of the dilematic 'debate' of the rational human effort, it can actually be understood that grouping of thoughts that developed in Frankfurt school deeply affected by the 'key' leaders. Especially if associated with a long history spectrum of the Frankfurt school, it can be found a variety of 'large' themes which tend to be 'different' to each other, but in the same spirit (critical philosophy). This tracing is essential to observe (the chronological) Frankfurt school.

In principal, the development of the critical theory of Frankfurt school can be divided into four periods: 
1. 1923 - 1933, an initial formation of Frankfurt School, the studies were empirical. At the beginning of the formation, the Frankfurt School was led by a professor of economics and history at the University of Frankfurt, Professor Carl Grumberg, a Marxist from Austria who were sympathetic to the 'idea' of Felix J. Weil and his friends.

2. 1933 - 1950, a period of exile to the United States, under the leadership of Max Hokhaimer, where the orientation of Frankfurt School was the neoHegelian critical theory.

3. 1950 - 1970, Frankfurt philosophers returned and had effect to the discourse of thought in Germany. In this period (as described above) the Frankfurt school effect was led by Herbert Marcuse and emerged the New Left movement run by the radical German students.

4. 1970 - The influence of Frankfurt began to decline, especially after the 'split' with the students who wanted a radical and total change. The deadlock was then broken by Jurgen Hebermas, and known as the second generation of Frankfurt school (Ardyan, 2001: 5859).

In the early development, led by Carl Grunbarg, the Frankfurt school had really tried to outline that the Social Research Institute was Marxist, 'the method taught as a theory to solve problems are marxist method' (Phil Slater, 1977: 2). However, as always stressed by Grunberg Weil: "the relationship with Marxism needs to be understood not in terms of political parties, but only in the scientific sense" (Phil Slater, 1977:3). At that timethe scientific of Marxist was really guarded, therefore Grunberg restricted its members to involve in the political party, and therefore to abstain from 'day to day politics (Sindhunata, 1983: 22).

After Grunberg, in early January 1931, the director for the Institute was Horkheimer who made the 'golden age' of the Institute and it was known as the Frankfurt School. In his opening speech, entitled "The Present State of Philosophy and the Sodul Task of on Insititute for Social Research; Horkheimer formulated his concept of social philosophy as 'philosophical interpretation of human destiny as far as human beings are not seen as individuals, but as members of society'. The Object of social philosophy is' all institutions are material and spiritual humanity as a whole (Sindhunata, 1983: 22-23).

This basic principle made Horkheimer criticize the conception of philosophy in the 'mean' of mere ideas, which cause individuals in the world do not able to capture the in depth 'philosophical significance' of these ideas. Freedom considered owned by the human beings, in fact, 'trapped' them in a variety of oppression and alienation, mainly carried out by the ruling class. That is why the great 'project' of Horkheimer was human liberation of the various 'shackles' caused by, particularly, ideology disrupting social reality. Therefore the theme of the critique of critical ideological seemed to be a new 'trend' to this genre during Horkheimer era. Demolition of this 'manipulative' ideology was the new face of Frankfurt school.

The effort to dismantle the ideology by the Critical Theory Horkheimer showed how he developed the theory of emancipatory praxis in favor of the public. 
In Horkheimer's hand, the Critical Theory used an emancipatory 'tool' to liberate the society from the prisons of authority (interests) hiden behind the 'cloak' of ideology. The society emancipation thus became the main personality of Horkheimer which later supported by Adorno and Herbert Marcuse, and also Jurgen Habermas.

The first criticism, introduced by Horkheimer, is about positivism in the social sciences, which supports the status quo, the people behind the guise of objectivity. The Positivism of social science was merely ideology of status quo, because it was considered that the social sciences, was value-free, free of social practice and morality, and can be used for prediction, objective, and so on. Such presumption became the common belief, that the only form of true knowledge was the scientific knowledge, and knowledge of this kind was simply obtained from the natural sciences (Hardiman, 1993: xvi - xvii).

Initiated by the conception of Horkheimer and his colleagues who considered that modern science, instead of creating an emancipative situation for the community, it helped the process of mechanization of society in the form of economic system and bureaucratic administration. Fascism, 'restrained' human freedom to think to 'victimizing' Gramsci because his liberalization thoughts and repressive Stalinism that had 'suppressed' the community was critical phenomenon to the Frankfurt school and referred as the oppressive crystallization ideology, but in the future the advance capitalist society and Western commonwelth countries were the phenomenon criticized by Habermas.
All the critical work essentially boiled down to the philosophy of critical theory through Public Criticism, that behind establisbment, there was an oppresive ideology, known or not. Thus the society must be freed from such oppression, so that they do not 'imprisoned' on a dogmatism in their thought and ideologicaly.

According to this spirit the Frankfurt school's emancipation movement found its 'estuary' in the Enlightenment (Aufklarung) era which was originally supported by the Frankfurt school with all of its emancipation project derived from the natural and social obstructions. But on the further developments, they turned to suspect enlightment as the culprit of the emergence of positivistic thinking which Horkheimer called as 'instrumental ratio', Adorno called it as identity thoughts, and Marcuse called it as the 'technological rationality' (Hardiman, 1993: xvii).

For Adorno and Horkheimer, the enlightenment effort through a project of eliminating the myths from ancient Greece logos with the critical ratio, particularly through science and technology, was apparently developed into a new myth, in a more subtle, more noble and more accepted by the modern people (Hardiman, 1993: xvii, and Sindhunata, 1983: xix $\mathrm{xx})$. The dominance of critical ratio in Aufklarung was in fact developed into a new ideology that 'silence' the critical power of modern society. When people are 'tied up' by a mainsream, that is when they are unconsiously trapped by the emerge of a new myth. Herbert Marcuse has the same oppinion (Marcuse, Herbert, 1964: 23). He criticized the construction of developed industrial society which he described as single-dimensional society. Without the 
second dimension or resistance againts the system, the industry's only adapt the dominance technocratism.

Further, the criticsm adopted by the Frankfrut school met its deadlock. Because the emancipation 'project' was in turn had become the new domination, the critique was merely the instrument of domination. In other word, a rational criticism was impossible. In today's society there is no room for criticism, because domination is total. The deadlock continues in a long period of time, after Jurgen Habernas (the second generation of Frankfurt school) presented a new paradigm in Critical Theory through its communication paradigm, the new 'phase' re-emerged from the school (Hardiman, 1993).

\section{The Epistemology of Frankfurt}

As explained above, the Frankfurt School is a diverse intellectual community. The Intellectuals who 'wrestle' in it are the representatives of various disciplines that have the same intellectual spirit, to re-raise the critical tradition that has been fading since Marxism became an ideology of the workers fights that had been 'suppressed' cruising force (the power) Marx thoughts that always seeks to develop a critical awareness of the society against all forms of oppression. However, it must be admitted that the characteristic of the thoughts apparently had left far behind the 'inspirator', Marx.

The critical tradition which was originally developed by Marx sought to dismantle the structure or system hidden in the veil of a certain ideologicals thinking that collects the societies creativity. It means that the the order grew (at the time) was actually a hidden place of ideological interests of certain parties. These interests would be 'dismantled' by Marx, which then continued by the Frankfurt School community that was popular with this 'ideological criticism'.

Frankfurt School's way of thinking is called the "Theory of Public Criticism" by its figures, it means to liberate people from the manipulation of modern technocrats. The typical of 'Theory of Public Criticism' is that this theory is contrary to the basic thought of Karl Marx, but at the same time is beyond and put him behind to face the problems of developed industrial societies in a new and creative way (Suseno, 1992: 160).

This critical paradigm is what later became the inspiration for the construction of models of thought, the Frankfurt School. The critical power is used as the knives and theme analysis of the intellectual struggle to produce sharp criticisms about the public, not only in terms of ideology, but also science and culture. Almost the entire society is the object of criticism, which is questionable, reviewed, and if necesary "destroyed" from top to the roots, to reveal the idelogy cover.

The most incisive critique of the Frankfurt School was aimed at the enlightenment project (Aufklarung) which totally failed in the anthropological paradox. The effort of modern people to liberate themselves from the shackles of myth or theological, which is 'taken for granted' has been rationalized human and nature itself. Rationalization in a critical sense is a rational act aimed at trying to master reality as efficient as possible for the sake of interests (economic, political, etc) (Adyan, 2001: 57). 
The critical paradigm which the Critical Theory attemped to develop was clearly different from the traditional philosophical thinking (of Hegel, Husserl, to Heidegger), which was not only contemplative, but also standed as the successor of Marx's ideals. As the emancipatory theory it tried to restore the freedom and future of mankind. Critical theory not only tried to explain, consider, reflect, categorize, and organize, but it also tried to change. It did not change the philosophy, but the destroying of human by the results of tehir own works (and perhaps including the capitalistic systems), therefore this theory was really practical (Suseno, 1992: 161-163).

In the context of Critical Theory, it was found that momen should always be closely related to the critique of the real social relations. The critical thinking reflects the society as well as theirselves in the context of dialectical structures of oppression and emancipation. The Critical Philosophy as an 'ammunition does not put as a pure theory, as if philosophy can be neutral in analyzing the substance of human and society without getting involved in it. Critical thinking considered themselve to be responsible toward a real social situation (Suseno, 1992: 175-176).

Implicitly as the emancipatory 'tool', Critical Theory must meet the following three requirements,:

1. To be critical and suspicious of its time, as done by their 'inspirator', Karl Marx against the capitalist system. The logical consequence of this attitude of style of thinking resulted in the refusal to be a doctrine. They are suspicious to all of doctrines.

2. Think historically is based on the community, of their 'historical' processes. It means the critical philosophy must always be dialectic with social reality as a target of criticism.

3. Separating the theory and praxis, does not release the facts of its value but merely to obtain the objective results (Ardyan, 2001: 59-60).

It should be understood that this 'critical' paradigm does not merely 'critisize' or 'suspicious' toward various irregularities in the society, but it is at first aware to the assumptions and social functions of theories, including this theory itself. This kind of thinking makes critical thinking not to trapped in the traditional theory. The emancipatorical critical theory has tried to be 'all out' and to be different from the traditional theory which is affirmative and status quo (anti change) pro. As known the traditional theory has been understood as the formulation of general and final principles in describing and interpreting reality. The traditional theory separates facts from values and tries to get the objective laws of reality. The traditional theory is informative and affirmative to the happened reality(Adyan, 2001: 60).

In such circumstances the traditional theory with objectivity has lost its critical power. It's as if something that has been said as objective, should be accepted. In fact, objectivity is the result of human action in history, the result of a history of oppression and exploitation. It would not be too much (Suseno, 1992: 179180) to say that in the next development, the traditional theory had served to the status quo of interest and supported the sustainability of the exist power structures. Under the veil of objectivity and freedom 
the 'traditional theory' had become the supporter to the power system based on oppression. Therefore, this theory is also trapped to be an ideology, or at least to be the 'means' of the interests of an ideology.

The critical theory showed up to critisize the impression of autonomy and objectivity in the claim of theoretical approaches. This theory had tried to be critical toward the positive status of the other theories. It became a critical movement in the form of theory and the thinking process. The critical theory exposed the theory of conditionals and the hidden implications in it. The critique did not come from outside of the theory, but let the existing theories to 'talk' about their philosophical desire or its claims (its ideals), so the lies and falses will reveal by themselves. Without 'showing' the weaknesses of a theory, especially the theory of positive (ism), exposing the theory or ideology on its claims will uncover its ideological veil.

Thus, the instability that previously protected by the positive theory is stripped. The mistaken reality is no longer seen as an objective reality, as it has become an open field for emancipative human action. Borrowing the terminology (Suseno, 1992, 180-181), the ideological had torn apart the veil of positive theories that given false legitimacy to the reality, the whole reality itself can be challenged. However one thing that should be the principal concern is that critical theory does not deal with objective laws and general principles of reality, but rather the effort to wake human up of their irrationality attached to the enlightenment project, as well as building the critical awareness of the public in order not to get caught dogmatically in using a theory or system, and ideology and without a reserve.
Every theory, system, and ideology must be accepted in a critical awareness.

The construction Frankfurt school's critical tradition is basically a result of a dialectic toward various thoughts previously developed. Although this school has Marxism as its starting point, but the critical tradition built and developed by the idealism of Kant, Hegel's dialectic doctrine, Karl Marx's critique of political economy, and the psychoanalysis of Sigmund Freud as its foundation of the critical epistemology.

In an interesting blend between the idealism of Kant, Hegel's and Marx's dialectics as well as Freud's, with various modifications that had made them relevant with the challenges of the era. All the three models of thoughts had viewed the word 'criticism' differently. Hegel views it as the reflection or self-reflection of the obstacles, pressures, and contradictions that obstruct the process of self-formation of the ratio in history. Karl Marx, as a Left Hegelian, views criticism as emancipatory efforts of oppression and aliensment generated by power relations in thesociety. WhileSigmud Freud views criticism as the individual liberation from irrationality to rationality, from unconsciousness into consciousness (Ardyan, 2001 and Sindhunata, 1983: 2961).

The critical paradigm developed as a result of the elaboration and modification placed by the Frankfurt school as 'the blade of analysis' to dismantle the various steadiness in social reality, which is shaped by ideology, theory, or system. The demolition "Project" continues over time, and many critics have been executed. However, the critiques has 'trapped' critical theory in a 'deadlock' and failure, particularly when explaining the modern 
liberation society (criticism) of the ideology and capitalism system. The development of critical was 'stuttering' with critics when facing vis-à-vis with the grip of the capitalist system in a modern society.

Criticisms offered by critical theory had its deadlock. The dominance occured is in fact has been so total that the critiques against capitalism can be coopted, and 'broken' by capitalism itself. The Hippies, for example, who rebelled against the behavior of the system through the 'eccentric' style with battered scooters, torn clothes, jeans, beaded necklace was in fact being co-opted by the modern capitalism by using the rebellion symbols as a new commodity. The jeans was made to be fashioned by presenting advertisement using a particular public figure and a slogan (for example): "the axe jeans, the rebel's jeans ". The working class is no longer a revolutionary because they are not a critical consumers (Ardyan, 2001, 75-76).

That is why, the criticisms by the Frankfurt school failed to make the critical theory as a catalyst and emansipator for modern society to be free from the chains (one of them is) capitalism. On the other hand, critical theory also considered as the cause of the emancipation 'campaigned' that has turned into the new domination. Criticism is no less than a new instrument of domination. As a result, in today's society there is no space for rational criticism, because domination (actually) is total; including the dominance of capitalism. The failure had made a sucessor and reformer of the Franfurt second generation attempted to revise it, he was Jurgen Habermas. He appeared as the reformer of Critical Theory who not only revealed the epistemological weaknesess of its predecessors, but also give a very fertile fundamental insight to continue the Critical Theory project through a new paradigm; from the critical paradigm to communication (Hardiman, 1993, Ardyan, 2001: 76-80).

\section{Conclusion}

More transparently, the basic framework of critical theory of the Frankfurt school is basically attempted to review its critical paradigm toward four (4) matters: the critique of ideology, the critique of positivism, the critique of the (construction of) modern society. Although, in its development it faced 'failure', but there was an attractive spirit, its intetion to implement the emantipation project to 'free' the society from the prisons of ideology, theory, and system interests which bind and suppress civil liberties. This theory wished to develop and build a critical public awareness of social reality surrounding it, with a 'suspicion'; behind every system, theory and ideology (steadyness) that might hide the oppression projects.

This basic spirit should be an inspiration for people in 'reading' the Society Criticism Theory of Frankfurt school. Despite all the shortcomings and weaknesses, this scgool has become an inspiration for the liberation efforts towards liberation and future of human(ity) that is free from all shackles of exploitation and oppression.

\section{REFERENCES}

Abdullah, T. dkk. (1974). Manusia dalam Kemelut Sejarah. Jakarta: LP3ES.

Adyan, D.G. (2001). Arus Pemikiran Kontemporer. Yogyakarta: Jalasutra. Bertens, K. (1981). Filsafat Barat dalam Abad XX. Jakarta: Gramedia. 
Effendi, E.A. (1999). Dekonstruksi Islam Mazhab Ciputat. Bandung: Mizan. Hardiman, B.F. (1993). Menuju Masyarakat Komunikatif, Ilmu, Masyarakat \& Politik Menurut Jurgen Habermas. Yogyakarta: Kanisius

Hadiwiyono, H. (1980). Sari Sejarah Filsafat, Jilid I. Yogyakarta: Kanisius.

Hardiman, B.F. (2003). Melampaui PositivismedanModernitas(Diskursus Filosofis tentang Merode Ilmiah dan Problem Modernitas). Yogyakarta: Kanisius.

Lechte, J. (2001). 50 Filsuf Kontemporer, dari Strukturalisme sampai Postmodernisme. Terjemahan oleh

A. Gunawan Admiranto. Yogyakarta: Kanisius.

Marcuse, H. (1964). One Dimensional Man, Studies in the Sociology of Advanced Industrial Society. London: Routledge \& Kegan Paul.

Ramly, A. M. (2000). Peta Pemikiran Karl Marx, Materialisme Dialektis dan Materialisme Historis. Yogyakarta: LKIS.
Sindhunata. (1982). Dilema Manusia Rasional, Kritik Masyarakat Modern oleh Marx Horkheimer dalam Rangka Sekolah Frankfurt. Jakarta: Gramedia. Slater, P. (1977). Origin and Significance of the Frankfurt School, A. Marxis Perspective. London: Routledge \& Kegan Paul,

Sugiharto, B. I. (1996). Posmodernisme: Tantangan Bagi Filsafat. Yogyakarta: Kanisius.

Suseno, F.M. (1999). Pemikiran Karl Marx, Dari Sosialisme Utopis ke Perselisihan Revisionisme. Jakarta: Gramedia.

Suseno, F.M. (1992). Filsafat Sebagai Ilmu Kritis. Yogyakarta: Kanisius.

Sutrisno,U \& Hardiman, B. F. (1992). Para Filsuf Penentu Gerak Zaman. Yogyakarta: Kanisius.

Titus, H.H. dkk. (1984). PersoalanPersoalan Filsafat. Jakarta: Bulan Bintang, 